\title{
Efficacy of Cognitive Behaviour Therapy and Quality Of Life in the Amputees
}

\author{
Rajendra Kumar Sharma ${ }^{1}$, Dr. Bhupender Singh ${ }^{2}$, Supriya Sharma ${ }^{3}$
}

\section{ABSTRACT}

The objective of the study was to assess the impact of cognitive behavior intervention in enhancing the quality of life in individuals with amputation. Methods: A sample of 100 patients with specified inclusion -exclusion criteria was selected and sequentially allotted (fifty each in experimental $n=50$ and control $n=50$ ) groups. An experimental design with pre-and post assessment was adopted. Assessment was done using Socio - demographic and clinical data sheet, World Health Organization Quality of Life Scale- Brief Version (WHOQOL). A cognitive-behavioral intervention programme was developed incorporating psycho education, behavioral techniques (e.g., relaxation, activity scheduling), cognitive techniques (e.g. distraction, cognitive restructuring) and behavioral counseling to significant others. Results: showed that on QOL was observed using the WHOQOL-BREF.QOL among the experimental group significant enhancements in Physical health domain, Psychological domain, Social domain, Environmental domain, overall QOL and overall health indicates that there significant improvement in QOL. There were no such changes in the Health habits subscale.

Keywords: Amputation, Quality Of Life, Cognition

Most of us are born as whole complete human beings. Mind and body is connected through nerves, muscle and bone. Unfortunately this system is sometimes torn apart by disease or unfortunate accidents. An amputation is a significant loss and can cause many lifestyle changes. Whether the limb is removed as a result of trauma, infection or disease, patients experience a change in their center of gravity, mobility and ability to perform activities of daily living like dressing, toileting and bathing.

Amputation is defined as - the surgical or spontaneous partial or complete removal of a limb or projecting body part covered by skin and is one of the most common acquired disabilities

${ }^{1}$ Clinical Psychologist, Army public School Bhopal, Bhopal, Madhya Pradesh

${ }^{2}$ Psychology, Army public School Bhopal, Bhopal, Madhya Pradesh

${ }^{3}$ Counselor, Army public School Bhopal, Bhopal, Madhya Pradesh

*Responding Author

(c) 2016 I R Sharma, B Singh, S Sharma; licensee IJIP. This is an Open Access Research distributed under the terms of the Creative Commons Attribution License (http://creativecommons.org/licenses/by/2.0), which permits unrestricted use, distribution, and reproduction in any Medium, provided the original work is properly cited. 


\section{Efficacy of Cognitive Behaviour Therapy and Quality Of Life in the Amputees}

(Rybarczyk, Edwards \& Behel, 2004). Individuals with amputations comprise a diverse clinical population, with significant heterogeneity observed in the level, cause, gender, and age distribution of this condition, as well as the degree of disability experienced, both physical and psychosocial (Gallagher \& Maclachlan, 2001).

\section{Incidence And Prevalence Of Amputation}

The global incidence of amputation is difficult to ascertain, as rates vary widely both between and within countries (Holman, Young \& Jeffcoate , 2012). The Global Amputation Study used a standard protocol to assess the incidence of lower limb amputation in ten different locations worldwide, and after twelve years remains the largest multinational study of its kind (Unwin, 2000). Marked differences in the incidence of lower limb amputation were observed between test centers, despite similarities in the age and sex distribution of amputations in their populations. For example, the annual incidence of first major amputations among males ranged from 2.8 cases per 100,000 of the population in Madrid, Spain, to 43.9 cases per 100,000 among the Navajo population in the United States. The significant variation observed across regions was attributed primarily to differences in the prevalence of diabetes and peripheral vascular disease (PVD).

\section{Morbidity And Mortality}

Major lower limb amputation is associated with considerable morbidity and mortality. Common postoperative complications include cardiac problems, pneumonia, and delayed wound healing due to infection or necrosis of the stump, which frequently necessitates revision of the amputation to a more proximal level of the affected limb (Aulivola, Ploeg, Lardenoye, Peeters \& Breslau, 2005). The risk of losing the contra lateral limb following unilateral amputation ranges from $15-20 \%$ within the first two years of the initial procedure, and rises to $40 \%$ by four years post-amputation (Cutson \& Bongiorni, 1996). There is evidence of increased morbidity among individuals with amputations secondary to diabetes, with the probability of experiencing cardiac failure and further amputation being twice as great as that observed among non-diabetic patients.

\section{Current Trends In Amputation}

Decreasing amputation rates among individuals with diabetes have been attributed to the growing use of innovative procedures to tackle dysvascularity, such as angioplasty and the prescription of lipid-lowering, antihypertensive and ant platelet medications. Preventive health care and education for persons with diabetes may also have played a significant role, with diabetic foot care programmes proving highly effective in preventing or delaying the need for amputation in this population. These developments, along with the overall aging of the population, have additionally contributed to an increase in the average age at which amputation is performed cross all etiologies.

\section{Quality Of Life And Amputation}

Physical part of the body was the most involved independent cause of amputation, whether it is due to vascular, traumatic or orthopedic causes, it is a mutilating surgery and it definitely affects 


\section{Efficacy of Cognitive Behaviour Therapy and Quality Of Life in the Amputees}

the lives of these patients. Quality of life automatically drops after losing any important part of one's body. Wald (2004) realized that given the complex physical and psychological issues involved in work related amputation, a comprehensive and holistic rehabilitation approach is recommended.

Singh (2008) conducted a study to explore the goal of rehabilitation after amputation and found that improvement an individual's mobility and integration back into the community affected attributes are the physical capacity, the physical, general state of health, the social aspects, the emotional aspects and the pain.

Burger and Marincek (2007) claimed that the ultimate objective of rehabilitation is to allow amputees to integrate into the community as independent and productive members. The impact upon the person and the process of adjustment to limb amputation is a highly complex and dynamic one that varies across individuals (Saradjian, Thompson \& Datta, 2008,). Although physical injuries can be treated through medical care and rehabilitation, the psychosocial impact can last for several months, years, or even throughout amputee's life. Besides, success of rehabilitation can be measured in many ways but a common outcome measure is successful fitting of prosthetic limb as use of prosthesis improves functional mobility and independence. Use of prosthesis is to restore body image and improve functioning in a cosmetically acceptable way (Saradjian, Thompson \& Datta, 2008). The process of adjusting to work-related amputation often involves cognitive, emotional, and behavioral adaptations (Wald, 2004).

There are many factors that have been investigated in moderating a person's psychological adjustment to losing a limb including patient demographics such as age, gender and level of education. Rehabilitation in general involves regaining an acceptable level of functioning and participation (Kelly \& Dowling, 2007). During the period shortly after amputation, Horgan \& MacLachlan, (2004) say depression has been reported as being the reason for decreased use of their prosthesis and lower level of mobility amongst people with long term amputations. There is a process of adjustment to prostheses, which also demonstrated the individuality of a person's relationship to it (Saradjian, Thompson \& Datta, 2008). Rehabilitation includes re-training and re-education of those who have become partially or wholly incapacitated (Kelly \& Dowling, 2007).

\section{Cognitive Behavioral Therapy}

Cognitive Behavior therapy defined as the psychotherapeutic approach based on learning principals in which treatment consists of identifying and modifying the maladaptive mediating and maintaining, cognitive, perceptual, behavioral, affective physiological and enviourmental factors. Modification implies eliminating/reducing the maladaptive and instilling/strengthening the adaptive behaviors .Cognitive Behavior therapy is a unique category of psychological intervention based on scientific models of human behavior cognition and emotion (Dobson, 2000).

\section{Socio Demographic and clinical data sheet:-}


This was developed for the present study to obtain demographic details, clinical data, personal and family history.

WHO Quality of Life Scale-Brief Version-The WHOQOL- BREF, development by WHO (1996), is a shorter version of WHOQOL-100 comprising of 26 items. The scale provides a measure of an individual's perception of quality of ife for the 4 domains 1 ) Physical health (7 items), 2) Psychological (6items), 3) Social relationship (3items) and 4), Environment (8 items). In addition to the 4 domains, it also includes 2 items from 'Overall Quality of Life' and 'General Health' facets. The internal consistency of WHOQOL -BRIEF as determined by chronbach 's alpha co-efficient ranges from $0.66-0.84$. The test- retest reliability (ranging from 2-8 weeks) is between $0.66-0.87$. The scale is also found to have good discriminant validity (The WHOQOL Group,1998). The domain scores are scaled in a positive direction (i.e. higher scores denote higher quality of life). Tool was used only once i.e. at pre-assessment, while tools 2-9 (all these tools self-rating measures) were used at pre and post -assessments.

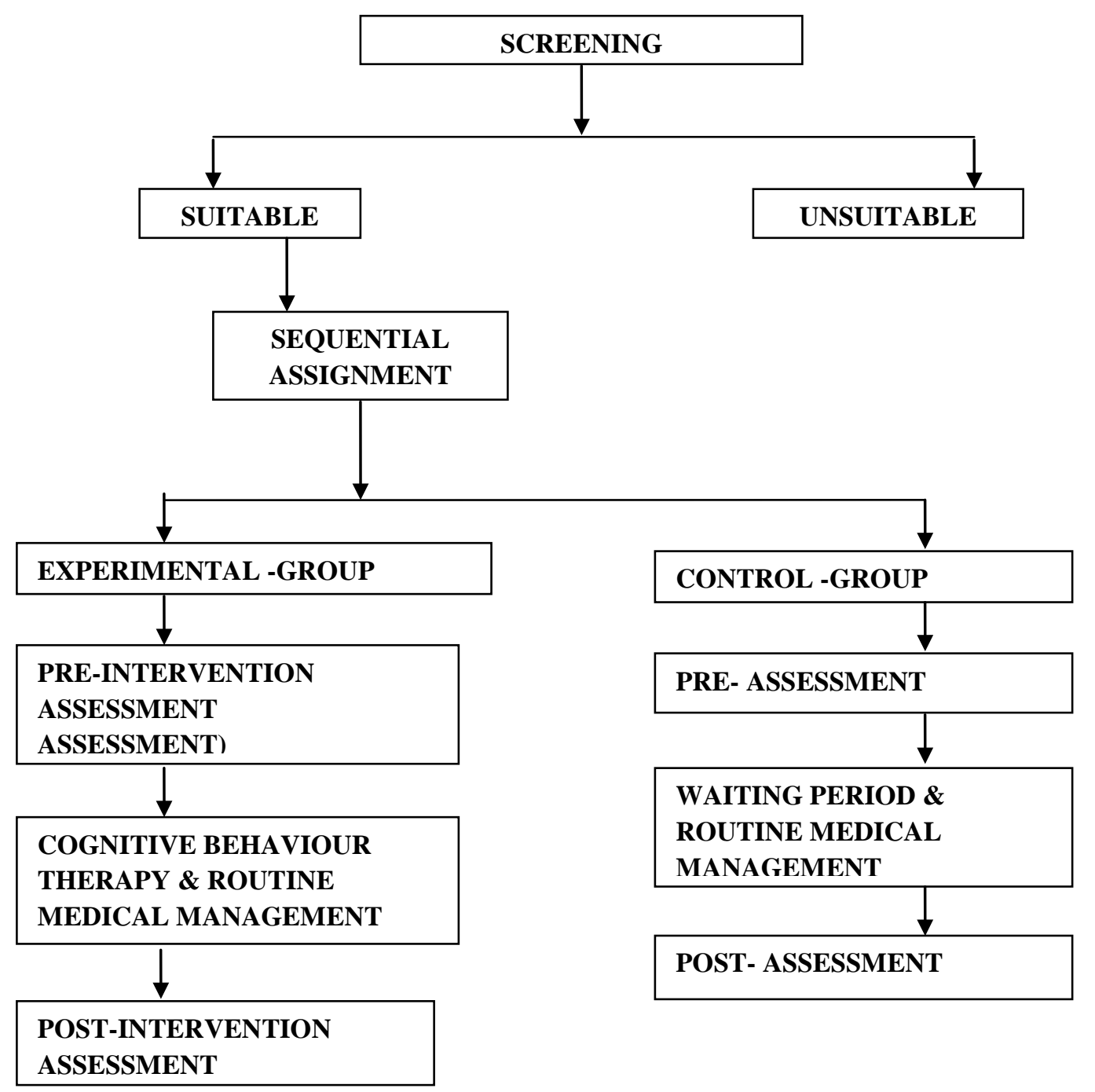


Efficacy of Cognitive Behaviour Therapy and Quality Of Life in the Amputees

Table 2: Sample characteristic Percentage wise for sex, education, occupation, marital status and income of amputee patients between Experimental and Control groups

\begin{tabular}{|c|c|c|c|c|c|}
\hline \multirow{2}{*}{\multicolumn{2}{|c|}{ CHARACTERISTICS }} & \multicolumn{2}{|c|}{$\begin{array}{l}\text { EXPERIMENTAL GROUP } \\
(\mathrm{N}=50)\end{array}$} & \multicolumn{2}{|c|}{$\begin{array}{l}\text { CONTROL GROUP } \\
(\mathrm{N}=50)\end{array}$} \\
\hline & & $\mathbf{N}$ & $\%$ & $\mathbf{n}$ & $\%$ \\
\hline \multirow[t]{4}{*}{ SEX } & & \multirow{3}{*}{40} & \multirow{3}{*}{80} & \multirow{3}{*}{45} & \multirow{3}{*}{90} \\
\hline & Male & & & & \\
\hline & \multirow[t]{2}{*}{ Female } & & & & \\
\hline & & 10 & 20 & 05 & 10 \\
\hline \multicolumn{6}{|c|}{ EDUCATION } \\
\hline & Primary & 17 & 34 & 15 & 30 \\
\hline & High School & 12 & 24 & 14 & 28 \\
\hline & Intermediate & 08 & 16 & 10 & 20 \\
\hline & Graduates & 09 & 18 & 08 & 16 \\
\hline & Post -Graduate & 04 & 08 & 03 & 06 \\
\hline \multicolumn{6}{|c|}{ OCCUPATION } \\
\hline & Unemployed & 19 & 38 & 20 & 40 \\
\hline & Employed & 15 & 30 & 15 & 30 \\
\hline & House wife & 08 & 16 & 08 & 16 \\
\hline & Students & 08 & 16 & 07 & 14 \\
\hline \multicolumn{6}{|c|}{ MARITAL STATUS } \\
\hline & Single & 16 & 32 & 15 & 30 \\
\hline & Married & 34 & 68 & 35 & 70 \\
\hline & Separated & - & - & - & - \\
\hline \multicolumn{2}{|c|}{ INCOME } & \multirow[b]{2}{*}{02} & \multirow{3}{*}{04} & \multirow[b]{2}{*}{03} & \multirow[b]{2}{*}{06} \\
\hline & $<$ Rs 1000 & & & & \\
\hline \multicolumn{2}{|c|}{ Between Rs 1000-2000 } & 08 & & 07 & 14 \\
\hline \multicolumn{2}{|c|}{ Between Rs 2000-3000 } & 12 & 24 & 09 & 18 \\
\hline$>$ & Rs $3000-4000$ & 28 & 56 & 31 & 62 \\
\hline
\end{tabular}

Table -2 indicates that majority of patients in both Experimental and Control group were male married belong to low income; Hindus and educated up to 5 to 10 years.88 percentage of the patients were unemployed. 
EFFICACY OF CBT IN ENHANCING QUALITY OF LI FE

Table -6: Showing means SD and ' $t$ ' values between Pre and Post assessment for Experimental and Control groups on the WHOQOL-BREF scores

\begin{tabular}{|c|c|c|c|c|c|c|}
\hline \multirow{3}{*}{$\begin{array}{l}\text { WHOQOL- } \\
\text { BREF }\end{array}$} & \multicolumn{4}{|c|}{ Experimental group $(n=50)$} & \multicolumn{2}{|c|}{ Control group $(n=50)$} \\
\hline & Pre & Post & 't' & Pre & Post & 't' Values \\
\hline & $\begin{array}{l}\text { Mean } \\
\text { (SD) }\end{array}$ & $\begin{array}{l}\text { Mean } \\
\text { (SD) }\end{array}$ & Values & $\begin{array}{l}\text { Mean } \\
\text { (SD) }\end{array}$ & $\begin{array}{l}\text { Mean } \\
\text { (SD }\end{array}$ & \\
\hline Physical health & $\begin{array}{l}43.22 \\
(11.75)\end{array}$ & $\begin{array}{l}67.50 \\
(10.55)\end{array}$ & $7.66^{* *}$ & $\begin{array}{l}48.34 \\
(15.55)\end{array}$ & $\begin{array}{l}51.77 \\
(15.45)\end{array}$ & 0.91 \\
\hline Psychological & $\begin{array}{l}54.67 \\
(15.68)\end{array}$ & $\begin{array}{l}65.84 \\
(13.82)\end{array}$ & $5.14 * *$ & $\begin{array}{l}51.78 \\
(16.45)\end{array}$ & $\begin{array}{l}53.23 \\
(22.29)\end{array}$ & 1.18 \\
\hline $\begin{array}{l}\text { Social } \\
\text { relationships }\end{array}$ & $\begin{array}{l}59.24 \\
(17.35)\end{array}$ & $\begin{array}{l}67.34 \\
(16.780\end{array}$ & $2.11^{*}$ & $\begin{array}{l}60.11 \\
(20.34)\end{array}$ & $\begin{array}{l}59.10 \\
(20.72)\end{array}$ & 1.39 \\
\hline Environment & $\begin{array}{l}49.23 \\
(18.12)\end{array}$ & $\begin{array}{l}66.12 \\
(14.06)\end{array}$ & $5.39 * *$ & $\begin{array}{l}52.78 \\
(16.23)\end{array}$ & $\begin{array}{l}56.18 \\
(14.95)\end{array}$ & 0.45 \\
\hline Overall QOL & $\begin{array}{l}3.12 \\
(1.39)\end{array}$ & $\begin{array}{l}4.34 \\
(0.81)\end{array}$ & $3.57 *$ & $\begin{array}{l}3.78 \\
(0.67)\end{array}$ & $\begin{array}{l}4.35 \\
(0.89)\end{array}$ & 0.57 \\
\hline Overall health & $\begin{array}{l}2.90 \\
(1.23)\end{array}$ & $\begin{array}{l}3.95 \\
(1.03)\end{array}$ & $4.13 * *$ & $\begin{array}{l}3.12 \\
(0.88)\end{array}$ & $\begin{array}{l}2.98 \\
(0.74)\end{array}$ & 0.97 \\
\hline
\end{tabular}

NS: $\quad$ Not Significant, ${ }^{*} \mathrm{p}<0.05,{ }^{* *} \mathrm{p}<0.01$

QOL scores show significant improvements in the Experimental group in all the domains. In addition, there were significant improvements in overall QOL and overall health in the experimental group. There were no such significant differences on any of the QOL scores in the control group. The mean scores for the experimental and control groups on WHOQOL-BREF at pre-and post assessments are depicted in Figs.6a and $6 \mathrm{~b}$. 
Figure 6.a: Showing mean scores of all domains for pre-and post assessment among Experimental group on WHOQOL-BREF

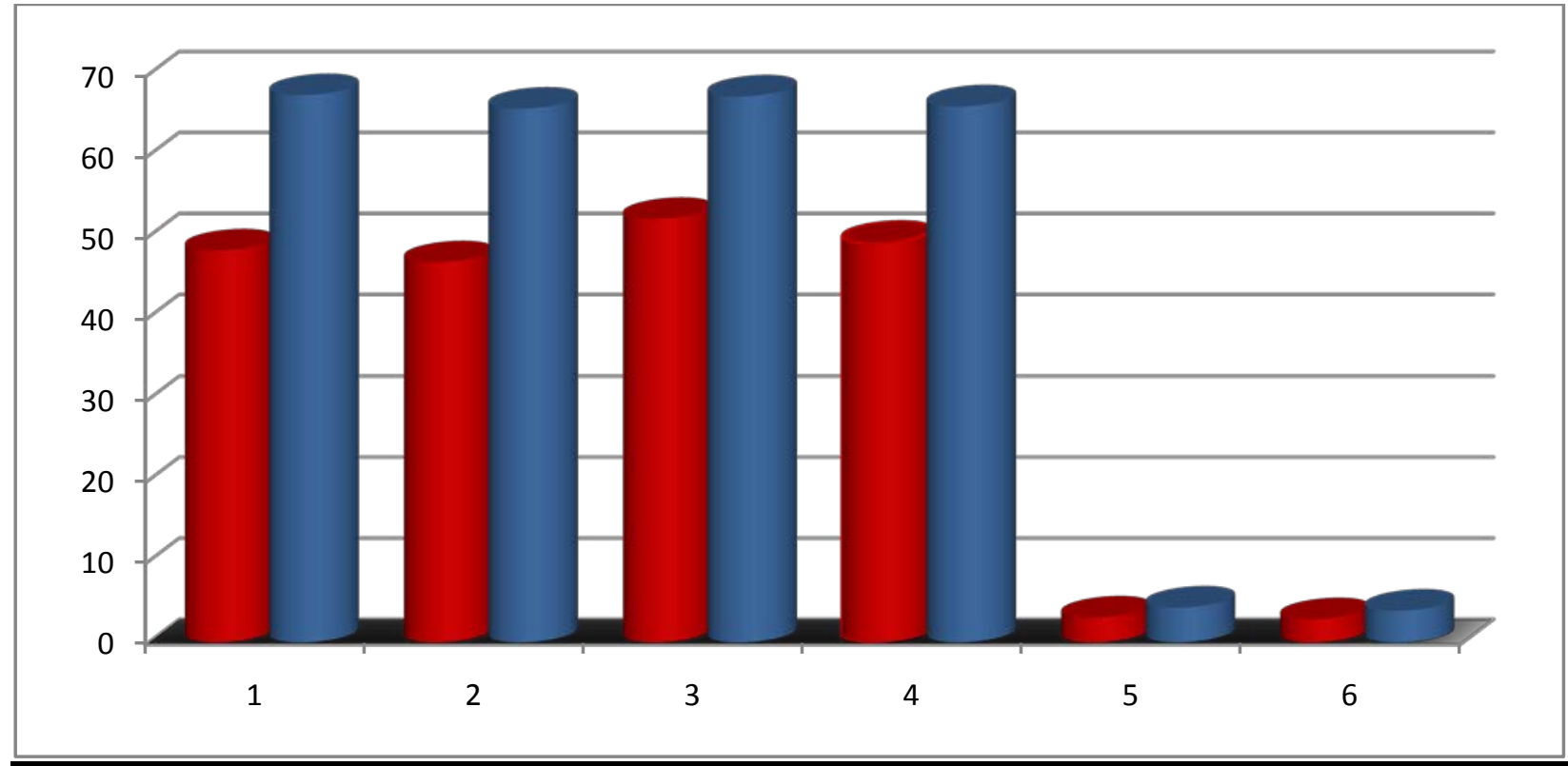

Table -6.a : Showing mean scores of all domains for pre-and post assessment among CONTROL group on WHOQOL-BREF

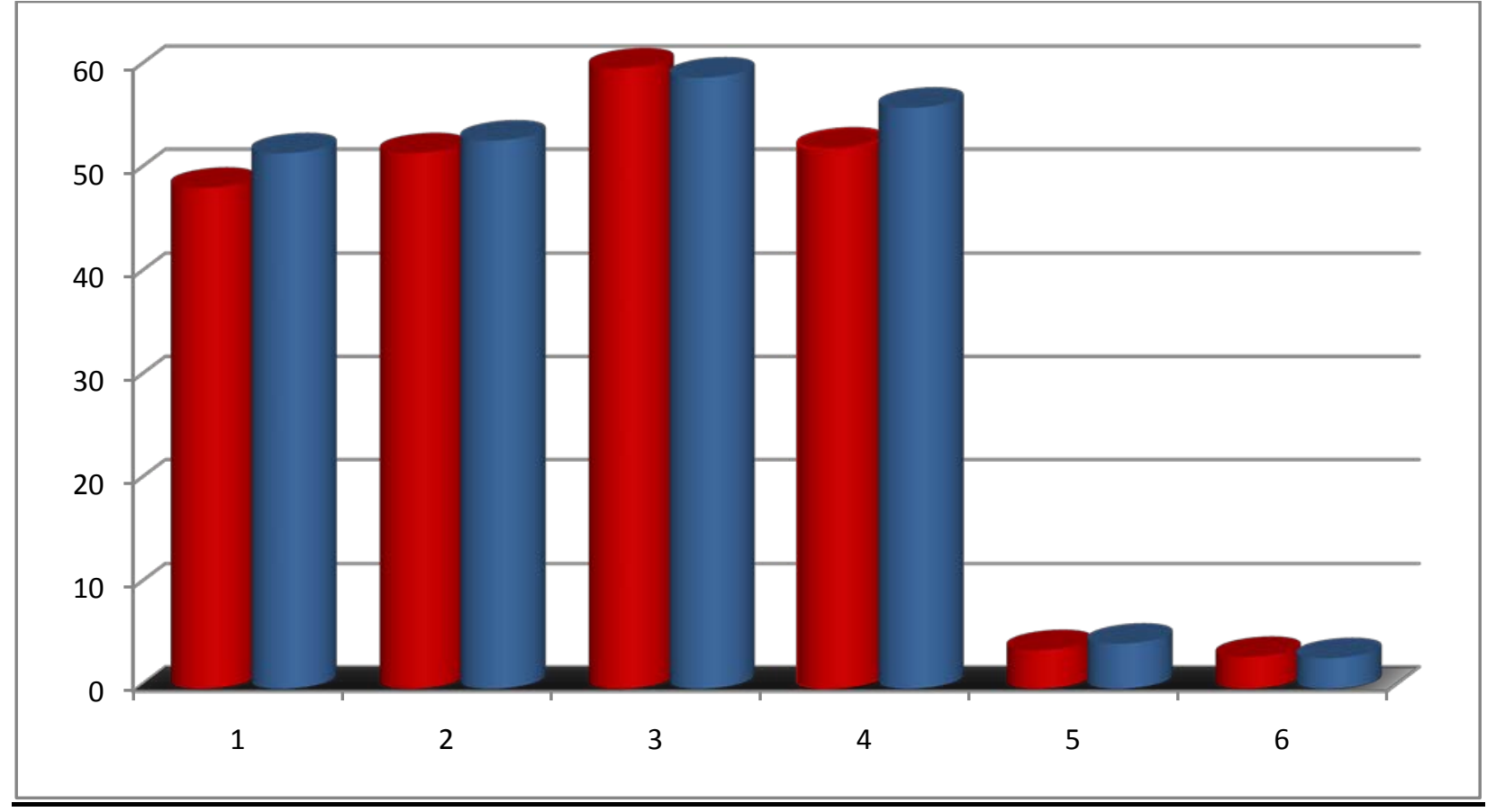




\section{DISCUSSION}

\section{Efficacy of CBT in enhancing quality of life (QOL)}

QOL was measured using the WHOQOL-BREF.QOL, as defined in the manual of this tools, is a broad concept, incorporating in a complex way, the person's physical features of their environment. The effect of CBT on these domains is discussed below.

Physical health domain: This is related to activities of daily living, energy and fatigue, pain and discomfort, sleep and work capacity. Significant differences were found on this domain in the Intervention group following intervention (see Table -6a). Improvement on this domain is characterised by decrease in pain intensity, improved sleep and work capacity.

Psychological domain: This includes items on bodily appearance, positive and negative feelings, self esteem, spirituality, thinking, memory and concentration. Table -6a indicates that the Intervention group patients showed significant improvement on this domain, while no such changes were seen in the control group. This indicates that the CBT helped increase self- esteem and decrease negative feelings anxiety, depressive cognition and sadness.

Social domain: This includes person al relationship, Social support and sexual activity. Table-6a indicates significant positive changes in the intervention group following CBT, while the control group did not show any such changes. The Experimental group participants thus reported significantly greater satisfaction in this domain. One may hypothesis that behavioral counseling to significant others, educating patients about communication and quipping them problem solving skills may account for the improvement in this domain.

Environmental domain: This includes items related to financial resources, physical safety and security, health care accessibility, home and physical environment, opportunities for acquiring information and skills, opportunity for recreation and transport facilities. Table- 6a shows that there were no significant changes in both the groups on this domain.

In addition, WHOQOL-BREF has two items, one each on overall QOL and overall health.Table-6a indicates that there significant improvement on both these items in the Experimental group while no such were seen in the Control Group.

In light of the positive changes o QOL among the Experimental group patient and no such changes in the control group, one may conclude that CBT was effective in enhancing QOL in patients with amputation.

Thus, the findings of the present study indicate that CBT is effective in reducing distress, disability and enhancing quality of life of patients with amputation. Table -6a-b: Showing mean scores of all domains for pre-and post assessment among Experimental group on WHOQOLBREF. 


\section{Efficacy of Cognitive Behaviour Therapy and Quality Of Life in the Amputees}

\section{BIBLIOGRAPHY:}

A psychometric evaluation of the Beck Depression Inventory-II. Psychological Assessment, 10(2), 83-89.

Ahmed, S., Mayo, N. E., Wood-Dauphinee, S., Hanley, J. A., \& Cohen, S. R. (2004). Response shift influenced estimates of change in health-related quality of life poststroke. Journal of Clinical Epidemiology, 57(6), 561-570.

Albrecht, G. L., \& Devlieger, P. J. (1999). The disability paradox: High quality of life against all odds. Social Science \& Medicine, 48, 977-988.

American Psychiatric Association, (1994). Diagnostic and statistical manual of mental disorders (4th ed.). Washington, DC: American Psychiatric Association. 215

Atkinson, J. W. (1964). An introduction to motivation. Oxford: Van Nostrand.

Aulivola, B., Hile, C. N., Hamdan, A. D., Sheahan, M. G., Veraldi, J. R., Skillman, J. J., et al. (2004). Major lower extremity amputation: Outcome of a modern series. Archives of Surgery, 139(4), 395-399.

Bach, J. R., \& Tilton, M. C. (1994). Life satisfaction and well-being measures in ventilator assisted individuals with traumatic tetraplegia. Archives of Physical Medicine and Rehabilitation, 75(6), 626-632.

Beck, A. T., Steer, R. A., \& Brown, G. K. (1996). Beck Depression Inventory manual (2nd ed.). San Antonio, TX: Psychological Corporation.

Behel, J. M., Rybarczyk, B., Elliott, T. R., Nicholas, J. J., \& Nyenhuis, D. (2002). The role of perceived vulnerability in adjustment to lower extremity amputation: A preliminary investigation. Rehabilitation Psychology, 47(1), 92-105.

Burger, H., \& Marinček, C. (1997). The life style of young person's after lower limb amputation caused by injury. Prosthetics \& Orthotics International, 21(1), 35-39.

Carver, C. S., \& Gaines, J. G. (1987). Optimism, pessimism, and postpartum depression. Cognitive Therapy and Research, 11(4), 449-462.

Comment on Morling and Evered (2006). Psychological Bulletin, 133(6), 911-916. cture of coping: A review and critique of category systems for classifying ways of coping. Psychological Bulletin, 129(3), 216-269.

Couture, M., Caron, C. D., \& Desrosiers, J. (2010). Leisure activities following a lower limb amputation. Disability \& Rehabilitation, 32(1), 57-64.

Crawford, J. R., \& Henry, J. D. (2004). The positive and negative affect schedule (PANAS): Construct validity, measurement properties and normative data in a large non-clinical sample. British Journal of Clinical Psychology, 43(3), 245-265. 226

Cutson, T. M., \& Bongiorni, D. R. (1996). Rehabilitation of the older lower limb amputee: A brief review. Journal of the American Geriatrics Society, 44(11), 1388-1393. Dahl,

D. M., Czerniecki, J. M., Smith, D. G., Campbell, K. M., Edwards, W. T., Jensen, M. P., et al. (2000). Chronic phantom sensations, phantom pain, residual limb pain, and other regional pain after lower limb amputation. Archives of Physical Medicine and Rehabilitation, 81(8), 1039-1044.

Darlington, A. S. E., Dippel, D. W. J., Ribbers, G. M., van Balen, R., Passchier, J., \& Busschbach, J. J. V. (2007). Coping strategies as determinants of quality of life in stroke patients: A longitudinal study. Cerebrovascular Diseases, 23(5-6), 401-407.

Darlington, A. S. E., Dippel, D. W. J., Ribbers, G. M., van Balen, R., Passchier, J., \& Busschbach, J. J. V. (2009). A prospective study on coping strategies and quality of life in patients after stroke, assessing prognostic relationships and estimates of cost- 


\section{Efficacy of Cognitive Behaviour Therapy and Quality Of Life in the Amputees}

effectiveness. Journal of Rehabilitation Medicine, 41(4), 237-241. Dozois, D. J. A., Dobson, K. S., \& Ahnberg, J. L. (1998).

Duke, J., Leventhal, H., Brownlee, S., \& Leventhal, E. A. (2002). Giving up and replacing activities in response to illness. The Journals of Gerontology Series B: Psychological Sciences and Social Sciences, 57(4), P367-P376.

Dunn, D. S., \& Elliott, T. R. (2008). The place and promise of theory in rehabilitation psychology research. Rehabilitation Psychology, 53(3), 254-267

Ehlers, A., Mayou, R. A., \& Bryant, B. (1998). Psychological predictors of chronic posttraumatic stress disorder after motor vehicle accidents. Journal of Abnormal Psychology, 107, 508-519.

Eker, D., Arkar, H., \& Yaldiz, H. (2000). Generality of support sources and psychometric properties of a scale of perceived social support in Turkey. Social Psychiatry and Psychiatric Epidemiology, 35(5), 228-233.

Ephraim, P. L., Wegener, S. T., MacKenzie, E. J., Dillingham, T. R., \& Pezzin, L. E. (2005). Phantom pain, residual limb pain, and back pain in amputees: Results of a national survey. Archives of Physical Medicine and Rehabilitation, 86(10), 1910-1919.

Esquenazi, A. (2004). Amputation rehabilitation and prosthetic restoration. From surgery to community reintegration. Disability \& Rehabilitation, 26(14-15), 831-836.

Faul, F., Erdfelder, E., Lang, A., \& Buchner, A. (2007). A flexible statistical power analysis program for the social, behavioral, and biomedical sciences. Behavior Research Methods, 39(2), 175-191. 235.

Fishbain, D. A., Cutler, R., Rosomoff, H. L., \& Rosomoff, R. S. (1997). Chronic pain-associated depression: Antecedent or consequence of chronic pain. A review. The Clinical Journal of Pain, 13(2), 116-137.

Fisher, K., \& Hanspal, R. S. (1998b). Phantom pain, anxiety, depression, and their relation in consecutive patients with amputated limbs: Case reports. British Medical Journal, 316(7135), 903-904.

Folkman, S. (1997). Positive psychological states and coping with severe stress. Social Science \& Medicine, 45(8), 1207-1221

Folkman, S., \& Lazarus, R. S. (1988). Manual for the Ways of Coping Questionnaire. Palo Alto, CA: Consulting Psychologists Press. Fosse, S., Hartemann-Heurtier, A., Jacqueminet, S., Ha Van, G., Grimaldi, A., \& Fagot-Campagna, A. (2009). Incidence and characteristics of lower limb amputations in people with diabetes. Diabetic Medicine, 26(4), 391-396.

Frank, R. G., Kashani, J. H., Kashani, S. R., Wonderlich, S. A., Umlauf, R. L., \& Ashkanazi, G. S. (1984). Psychological response to amputation as a function of age and time since amputation. The British Journal of Psychiatry, 144, 493-497.

G., Klomp, H., Steyerberg, E., \& Habbema, J. (2000). Pain and quality of life in patients with critical limb ischaemia: Results of a randomized controlled multicentre study on the effect of spinal cord stimulation. European Journal of Pain, 4(2), 173-184.

Gallagher, P., \& Desmond, D. (2007). Measuring quality of life in prosthetic practice: Benefits and challenges. Prosthetics \& Orthotics International, 31(2), 167-176.

Gallagher, P., \& MacLachlan, M. (2004). The Trinity Amputation and Prosthesis Experience Scales and quality of life in people with lower-limb amputation. Archives of Physical Medicine and Rehabilitation, 85(5), 730-736.

Gallagher, P., Franchignoni, F., Giordano, A., \& MacLachlan, M. (2010). Trinity Amputation and Prosthesis Experience Scales: A psychometric assessment using classical test theory and Rasch analysis. American Journal of Physical Medicine \& Rehabilitation, 89(6), 487496. 


\section{Efficacy of Cognitive Behaviour Therapy and Quality Of Life in the Amputees}

Garnefski, N., Kraaij, V., De Graaf, M., \& Karels, L. (2010). Psychological intervention targets for people with visual impairments: The importance of cognitive coping and goal adjustment. Disability \& Rehabilitation, 32(2), 142-147.

Geertzen, J. H. B., Van Es, C. G., \& Dijkstra, P. U. (2009). Sexuality and amputation: A systematic literature review. Disability \& Rehabilitation, 31(7), 522-527.

Guilford. 265 Polatinsky, S., \& Esprey, Y. (2000). An assessment of gender differences in the perception of benefit resulting from the loss of a child. Journal of Traumatic Stress, 13(4), 709-718.

H. G. M. (1999). Predicting functional status in patients with rheumatoid arthritis. Journal of Rheumatology, 26(8),

1686-1693. Scheier, M. F., \& Carver, C. S. (2003). Self-regulatory processes and responses to health threats: Effects of optimism on well-being. In J. Suls, \& K. A. Wallston (Eds.), Social psychological foundations of health (pp. 395-428). Malden, MA: Blackwell Publishing Ltd.

Hamill, R., Carson, S., \& Dorahy, M. (2010). Experiences of psychosocial adjustment within 18 months of amputation: An interpretative phenomenological analysis. Disability \& Rehabilitation, 32(9), 729-740.

Hanley, M. A., Jensen, M. P., Ehde, D. M., Hoffman, A. J., Patterson, D. R., \& Robinson, L. R. (2004). Psychosocial predictors of long-term adjustment to lower-limb amputation and phantom limb pain. Disability \& Rehabilitation, 26(14), 882-893. 243

Hill, A., Niven, C. A., \& Knussen, C. (1995). The role of coping in adjustment to phantom limb pain. Pain, 62(1), 79-86.

Hopp, G. A., Dixon, R. A., Grut, M., \& Bäckman, L. (1997). Longitudinal and psychometric profiles of two cognitive status tests in very old adults. Journal of Clinical Psychology, 53(7), 673-686.

Horgan, O., \& MacLachlan, M. (2004). Psychosocial adjustment to lower-limb amputation: A review. Disability \& Rehabilitation, 26(14), 837-850. 245

J. A., Danoff-Burg, S., \& Revenson, T. A. (2005). Benefit-finding among patients with rheumatoid arthritis: Positive effects on interpersonal relationships. Journal of Behavioral Medicine, 28(1), 91-103. 227

Jensen, M. P., Ehde, D. M., Hoffman, A. J., Patterson, D. R., Czerniecki, J. M., \& Robinson, L. R. (2002). Cognitions, coping and social environment predict adjustment to phantom limb pain. Pain, 95(1-2), 133-142. 246

Kashani, J. H. (1983). Depression among amputees. Journal of Clinical Psychiatry, 44(7), 256-258.

Katz, J. (1992). Psychophysical correlates of phantom limb experience. Journal of Neurology, Neurosurgery \& Psychiatry, 55, 811-821

Kohler, F., Cieza, A., Stucki, G., Geertzen, J., Burger, H., Dillon, M. P., et al. (2009). Developing core sets for persons following amputation based on the International Classification of Functioning, Disability and Health as a way to specify functioning. Prosthetics and Orthotics International, 33(2), 117-129. 248

Kraaij, V., Garnefski, N., \& Schroevers, M. J. (2009). Coping, goal adjustment, and positive and negative affect in definitive infertility. Journal of Health Psychology, 14(1), 18.

Kratz, A. L., Williams, R. M., Turner, A. P., Raichle, K. A., Smith, D. G., \& Ehde, D. (2010). To lump or to split? Comparing individuals with traumatic and no traumatic limb loss in the first year after amputation. Rehabilitation Psychology, 55(2), 126-138.

Legro, M. W., Reiber, G. D., Smith, D. G., del Aguila, M., Larsen, J., \& Boone, D. (1998). Prosthesis evaluation questionnaire for persons with lower limb amputations: Assessing 


\section{Efficacy of Cognitive Behaviour Therapy and Quality Of Life in the Amputees}

prosthesis-related quality of life, Archives of Physical Medicine and Rehabilitation, 79(8), 931-938.

Levine, B., Robertson, I. H., Clare, L., Carter, G., Hong, J., Wilson, B. A., et al. (2000). Rehabilitation of executive functioning: An experimental-clinical validation of goal management training. Journal of the International Neuropsychological Society, 6(3), 299-312.

Livneh, H., \& Wilson, L. M. (2003). Coping strategies as predictors and mediators of disabilityrelated variables and psychosocial adaptation: An exploratory investigation. Rehabilitation Counseling Bulletin, 46(4), 194-208.

M., Lotfy, M., \& O'Connell, K. A. (2004). The World Health Organization's WHOQOL-BREF quality of life assessment: Psychometric properties and results of the international field trial. A report from the WHOQOL group. Quality of Life Research, 13(2), 299-310.

MacLachlan, M., \& Gallagher, P. (2004). Enabling technologies: Body image and body function. Edinburgh: Churchill Livingstone.

Maguire, P., \& Parkes, C. M. (1998). Coping with loss: Surgery and loss of body parts. British Medical Journal, 316, 1086-1088. 253

Murray, C. D. (2010). Gender, sexuality and prosthesis use: Implications for rehabilitation. In C. D. Murray (Ed.), Amputation, prosthesis use, and phantom limb pain: An interdisciplinary perspective (pp. 115-127).

National Amputee Statistical Database. (2009). The amputee statistical database for the United Kingdom 2006/07. Edinburgh: Information Services Division, NHS Scotland.

Nissen, S. J., \& Newman, W. P. (1992). Factors influencing reintegration to normal living after amputation. Archives of Physical Medicine and Rehabilitation, 73(6), 548-551.

Novy, D. M., Nelson, D. V., Francis, D. J., \& Turk, D. C. (1995). Perspectives of chronic pain: An evaluative comparison of restrictive and comprehensive models. Psychological Bulletin, 118(2), 238-247

Oaksford, K., Frude, N., \& Cuddihy, R. (2005). Positive coping and stress-related psychological growth following lower limb amputation. Rehabilitation Psychology, 50(3), 266-277

Offerman, M. P. J., Schroevers, M. J., van der Velden, L. A., de Boer, M. F., \& Pruyn, J. F. A. (2010). Goal processes \& self-efficacy related to psychological distress in head \& neck cancer patients and their partners. European Journal of Oncology Nursing, 14(3), 231-237. 257

Oldridge, N., Guyatt, G., Crowe, J., Feeny, D., \& Jones, N. (1999). Goal attainment in a randomized controlled trial of rehabilitation after myocardial infarction. Journal of Cardiopulmonary Rehabilitation and Prevention, 19(1), 29-34.

Orbell, S., Johnston, M., Rowley, D., Davey, P., \& Espley, A. (2001). Self-efficacy and goal importance in the prediction of physical disability in people following hospitalization: A prospective study. British Journal of Health Psychology, 6(1), 25-40.

Owings, M. F., \& Kozak, L. J. (1998). Ambulatory and inpatient procedures in the United States, 1996. Vital Health Statistics, 13(139), 1-127.

Park, C. L. (2010). Making sense of the meaning literature: An integrative review of meaning making and its effects on adjustment to stressful life events. Psychological Bulletin, 136(2), 257301.

Park, C. L., \& Folkman, S. (1997). Meaning in the context of stress and coping. Review of General Psychology, 1(2), 115-144.

Parkes, C. M. (1975). Psycho-social transitions: Comparison between reactions to loss of a limb and loss of a spouse. British Journal of Psychiatry, 127, 204-210. 258 


\section{Efficacy of Cognitive Behaviour Therapy and Quality Of Life in the Amputees}

Pell, J. P., Donnan, P. T., Fowkes, F. G., \& Ruckley, C. V. (1993). Quality of life following lower limb amputation for peripheral arterial disease. European Journal of Vascular Surgery, 7(4), 448-451.

Pernot, H. F. M., De Witte, L. P., Lindeman, E., \& Cluitmans, J. (1997). Daily functioning of the lower extremity amputee: An overview of the literature. Clinical Rehabilitation, 11(2), 93-106.

Pezzin, L. E., Dillingham, T. R., \& MacKenzie, E. J. (2000). Rehabilitation and the long-term outcomes of persons with trauma-related amputations. Archives of Physical Medicine and Rehabilitation, 81(3), 292-300.

Phelps, L. F., Williams, R. M., Raichle, K. A., Turner, A. P., \& Ehde, D. M. (2008). The importance of cognitive processing to adjustment in the 1st year following amputation. Rehabilitation Psychology, 53(1), 28-38.

Ploeg, A. J., Lardenoye, J. -W., Vrancken Peeters, M. -P. F. M., \& Breslau, P. J. (2005). Contemporary series of morbidity and mortality after lower limb amputation. European Journal of Vascular and Endovascular Surgery, 29(6), 633-637. 259

Polliack, A. A., \& Moser, S. (1997). Facing the future of orthotics and prosthetics proactively: Theory and practice of outcomes measures as a method for determining quality of services. Journal of Prosthetics and Orthotics, 9(3), 127-134.

Ptacek, J. T., \& Pierce, G. R. (2003). Issues in the study of stress and coping in rehabilitation settings. Rehabilitation Psychology, 48(2), 113-124.

Pucher, I., Kickinger, W., \& Frischenschlager, O. (1999). Coping with amputation and phantom limb pain. Journal of Psychosomatic Research, 46(4), 379-383. 260

Raichle, K. A., Hanley, M. A., Molton, I., Kadel, N. J., Campbell, K., Phelps, E., et al. (2008). Prosthesis use in persons with lower-and upper-limb amputation. Journal of Rehabilitation Research and Development, 45(7), 961-972

Robinson, V., Sansam, K., Hirst, L., \& Neumann, V. (2010). Major lower limb amputation-what, why and how to achieve the best results. Orthopaedics and Trauma, 24(4), 276-285.

Roemer, L., Orsillo, S. M., \& Salters-Pedneault, K. (2008). Efficacy of an acceptance-based behavior therapy for generalized anxiety disorder: Evaluation in a randomized controlled trial. Journal of Consulting and Clinical Psychology, 76(6), 1083-1089. 261

Rothermund, K., \& Brandtstädter, J. (2003). Depression in later life: Cross-sequential patterns and possible determinants. Psychology and Aging, 18(1), 80-90.

Rothermund, K., \& Brandtstädter, J. (2003). Depression in later life: Cross-sequential patterns and possible determinants. Psychology and Aging, 18(1), 80-90.

Rushton, P. W., \& Miller, W. C. (2002). Goal attainment scaling in the rehabilitation of patients with lower-extremity amputations: A pilot study. Archives of Physical Medicine and Rehabilitation, 83(6), 771-775.

Rushton, P. W., \& Miller, W. C. (2002). Goal attainment scaling in the rehabilitation of patients with lower-extremity amputations: A pilot study. Archives of Physical Medicine and Rehabilitation, 83(6), 771-775.

Ryan, E. B., Anas, A. P., Beamer, M., \& Bajorek, S. (2003). Coping with age-related vision loss in everyday reading activities. Educational Gerontology, 29(1), 37-54.

Ryan, E. B., Anas, A. P., Beamer, M., \& Bajorek, S. (2003). Coping with age-related vision loss in everyday reading activities. Educational Gerontology, 29(1), 37-54.

Rybarczyk, B. D., Nyenhuis, D. L., Nicholas, J. J., Schulz, R., Alioto, R. J., \& Blair, C. (1992). Social discomfort and depression in a sample of adults with leg amputations. Archives of Physical Medicine \& Rehabilitation, 73(12), 1169-1173. 


\section{Efficacy of Cognitive Behaviour Therapy and Quality Of Life in the Amputees}

Rybarczyk, B. D., Nyenhuis, D. L., Nicholas, J. J., Schulz, R., Alioto, R. J., \& Blair, C. (1992). Social discomfort and depression in a sample of adults with leg amputations. Archives of Physical Medicine \& Rehabilitation, 73(12), 1169-1173.

Rybarczyk, B., Edwards, R., \& Behel, J. (2004). Diversity in adjustment to a leg amputation: Case illustrations of common themes. Disability \& Rehabilitation, 26(14), 944-953.

Rybarczyk, B., Edwards, R., \& Behel, J. (2004). Diversity in adjustment to a leg amputation: Case illustrations of common themes. Disability \& Rehabilitation, 26(14), 944-953.

Rybarczyk, B., Nicholas, J. J., \& Nyenhuis, D. L. (1997). Coping with a leg amputation: Integrating research and clinical practice. Rehabilitation Psychology, 42(3), 241-256. 262

Rybarczyk, B., Nicholas, J. J., \& Nyenhuis, D. L. (1997). Coping with a leg amputation: Integrating research and clinical practice. Rehabilitation Psychology, 42(3), 241-256. 262

Rybarczyk, B., Szymanski, L., \& Nicholas, J. J. (2000). Limb amputation. In R. G. Frank, \& T. R. Elliott (Eds.), Handbook of rehabilitation psychology (pp. 29-47). Washington, DC: American Psychological Association.

Rybarczyk, B., Szymanski, L., \& Nicholas, J. J. (2000). Limb amputation. In R. G. Frank, \& T. R. Elliott (Eds.), Handbook of rehabilitation psychology (pp. 29-47). Washington, DC: American Psychological Association.

Saradjian, A., Thompson, A. R., \& Datta, D. (2008). The experience of men using an upper limb prosthesis following amputation: Positive coping and minimizing feeling different. Disability \& Rehabilitation, 30(11), 871-883.

Scheier, M. F., \& Carver, C. S. (1985). Optimism, coping and health: Assessment and implications of generalized outcome expectancies. Health Psychology, 4(3), 219-247.

Scheier, M. F., Carver, C. S., \& Bridges, M. W. (1994). Distinguishing optimism and neuroticism (and trait anxiety, self-mastery, and self-esteem): A reevaluation of the Life Orientation Test. Journal of Personality and Social Psychology, 67(6), 1063-1078. 263

Schoppen, T., Boonstra, A., Groothoff, J. W., de Vries, J., Goeken, L. N., \& Eisma, W. H. (2003). Physical, mental, and social predictors of functional outcome in unilateral lowerlimb amputees. Archives of Physical Medicine and Rehabilitation, 84(6), 803-811.

Schoppen, T., Boonstra, A., Groothoff, J. W., van Sonderen, E., Göeken, L. N., \& Eisma, W. H. (2001). Factors related to successful job reintegration of people with a lower limb amputation. Archives of Physical Medicine and Rehabilitation, 82(10), 1425-1431.

Schroevers, M., Kraaij, V., \& Garnefski, N. (2007). Goal disturbance, cognitive coping strategies, and psychological adjustment to different types of stressful life event. Personality and Individual Differences, 43(2), 413-423. 264

Schroevers, M., Kraaij, V., \& Garnefski, N. (2008). How do cancer patients manage unattainable personal goals and regulate their emotions? British Journal of Health Psychology, 13(3), 551-562.

Schwartz, L. A., \& Drotar, D. (2009). Health-related hindrance of personal goal pursuit and wellbeing of young adults with cystic fibrosis, pediatric cancer survivors, and peers without a history of chronic illness. Journal of Pediatric Psychology, 34, 954-965.

Seligman, M. E. P., \& Csikszentmihalyi, M. (2000). Positive psychology: An introduction. American Psychologist, 55(1), 5-14.

Senra, H., Oliveira, R. A., Leal, I., \& Vieira, C. (2012). Beyond the body image: A qualitative study on how adults experience lower limb amputation. Clinical Rehabilitation, 26(2), 180-191.

Shaver, P. R., \& Fraley, R. C. (2008). Attachment, loss, and grief: Bowlby's views and current controversies. In J. Cassidy, \& P. Shaver (Eds.), Handbook of attachment: Theory, research, and clinical applications (2nd ed., pp. 48-77). New York: 


\section{Efficacy of Cognitive Behaviour Therapy and Quality Of Life in the Amputees}

Siegert, R. J., McPherson, K. M., \& Taylor, W. J. (2004). Toward a cognitive-affective model of goal-setting in rehabilitation: Is self-regulation theory a key step? Disability \& Rehabilitation, 26(20), 1175-1183.

Singh, R., Ripley, D., Pentland, B., Todd, I., Hunter, J., Hutton, L., et al. (2009). Depression and anxiety symptoms after lower limb amputation: The rise and fall. Clinical Rehabilitation, 23(3), 281-286.

Sinha, R., \& Van Den Heuvel, W. J. A. (2011). A systematic literature review of quality of life in lower limb amputees. Disability \& Rehabilitation, 33(11), 883-899.

Sinha, R., Van Den Heuvel, W. J. A., \& Arokiasamy, P. (2011). Factors affecting quality of life in lower limb amputees. Prosthetics and Orthotics Internatio Spincemaille,

Smout, S., Koudstaal, P. J., Ribbers, G. M., Janssen, W. G. M., \& Passchier, J. (2001). Struck by stroke: A pilot study exploring quality of life and coping patterns in younger patients and spouses. International Journal of Rehabilitation Research, 24(4), 261-268.

Snyder, C. R. (2002). Hope theory: Rainbows in the mind. Psychological Inquiry, 13(4), 249-275.

Snyder, C. R., Irving, L. M., \& Anderson, J. R. (1991). Hope and health. In D. R. Forsyth, \& C. R. Snyder (Eds.), (pp. 285-305). Elmsford, NY: Pergamon Press. 267

Sprangers, M. A. G., \& Schwartz, C. E. (1999). Integrating response shift into health-related quality of life research: A theoretical model. Social Science \& Medicine, 48(11), 1507-1515.

Stanley, M. A., Beck, J. G., \& Zebb, B. J. (1998). Psychometric properties of the MSPSS in older adults. Aging and Mental Health, 2(3), 186-193. 268

Stanton, A. L., Danoff-Burg, S., Cameron, C. L., Bishop, M., Collins, C. A., Kirk, S. B., et al. (2000). Emotionally expressive coping predicts psychological and physical adjustment to breast cancer. Journal of Consulting and Clinical Psychology, 68(5), 875-882.

Taylor, S. E. (2007). Social support. In H. S. Friedman, \& R. C. Silver (Eds.), Foundations of health psychology (pp. 145-171). New York: Oxford University Press.

Taylor, S. E. (2007). Social support. In H. S. Friedman, \& R. C. Silver (Eds.), Foundations of n health psychology (pp. 145-171). New York: Oxford University Press.

Tedeschi, R. G., \& Calhoun, L. G. (1996). The Posttraumatic Growth Inventory: Measuring the positive legacy of trauma. Journal of Traumatic Stress, 9(3), 455-471.

Tedeschi, R. G., \& Calhoun, L. G. (2004). Posttraumatic growth: Conceptual foundations and empirical evidence. Psychological Inquiry, 15(1), 1-18.

Thompson, D. M., \& Haran, D. (1983). Living with an amputation: The patient. Disability \& Rehabilitation, 5(4), 165-169.

Thompson, M., Sayers, R., Reid, A., Underwood, M., \& Bell, P. (1995). Quality of life following infragenicular bypass and lower limb amputation. European Journal oVascular and Endovascular Surgery, 9(3), 310-313.

Tombaugh, T. N., \& McIntyre, N. J. (1992). The mini-mental state examination: A comprehensive review. Journal of the American Geriatrics Society, 40(9), 922-935.

Trautner, C., Haastert, B., Mauckner, P., Gatcke, L., \& Giani, G. (2007). Reduced incidence of lower-limb amputations in the diabetic population of a German city, 1990-2005. Diabetes Care, 30(10), 2633-2637.

Trunzo, J. J., \& Pinto, B. M. (2003). Social support as a mediator of optimism and distress in breast cancer survivors. Journal of Consulting and Clinical Psychology, 71(4), 805-811.

Turk, D. C., Dworkin, R. H., Burke, L. B., Gershon, R., Rothman, M., Scott, J., et al. (2006). Developing patient-reported outcome measures for pain clinical trials: IMMPACT recommendations. Pain, 125(3), 208-215. 271 Unwin, J., Kacperek, L., \& Clarke, C. 


\section{Efficacy of Cognitive Behaviour Therapy and Quality Of Life in the Amputees}

(2009). A prospective study of positive adjustment to lower limb amputation. Clinical Rehabilitation, 23(11), 1044-1050.

Unwin, N. (2000). Global lower extremity amputation study group: Epidemiology of lower extremity amputation in centres in Europe, North America and East Asia. British Journal of Surgery, 87(3), 328-337

Üstün, T., Kostanjsek, N., \& Chatterji, S. (2010). Measuring Health and Disability: Manual for WHO Disability Assessment Schedule WHODAS 2.0. Geneva: World Health Organization.

How to cite this article: R Sharma, B Singh, S Sharma (2016), Efficacy of Cognitive Behaviour Therapy and Quality Of Life in the Amputees, International Journal of Indian Psychology, Volume 3, Issue 3, No. 7, DIP: 18.01.130/20160303, ISBN: 978-1-365-12175-3 